Tips om medisinsk litteratur, andre bøker, filmer og elektroniske medier > som bør anmeldes, sendes tidsskriftet@legeforeningen.no

\section{Også barna må ses!}

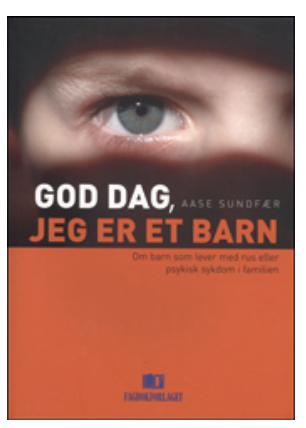

\section{Aase Sundfær}

\section{God dag, jeg er et barn}

Om barn som lever med rus eller psykisk

sykdom i familien. 210 s. Bergen:

Fagbokforlaget, 2012. Pris NOK 349

ISBN 978-82-450-1047-3

Familieperspektiv er viktig både innen helsetjeneste og barnevern. Det er vi nylig blitt minnet om både i ulike medier og i fagpresse. Lov om helsepersonell fastslår at helseinstitusjoner som omfattes av loven, har plikt til å ha barneansvarlig personell som skal «fremme og koordinere helsepersonells oppfølging av mindreårige barn av psykisk syke, rusmiddelavhengige og alvorlig syke eller skadde pasienter». Temaet er derfor meget aktuelt.

Forfatteren er sosionom med bred klinisk erfaring og kunnskaper, bl.a. basert på oppfølging gjennom 25 år av barna til en gruppe mødre med rusproblemer og psykiske vansker. I de ni kapitlene omtaler hun i kronologisk rekkefølge familie- og foreldreatferd, svangerskap og fødsel og barns utvikling fra nyfødt til ung voksen alder. Dette belyser hun med en rekke eksempler. Enkelte kapitler har faktarammer, hvor forfatteren summerer opp karakteristika ved samspill når foreldrene er syke, eller gir forslag til førstegangssamtale med foreldre til barn i ulike aldersgrupper og samtale med barna. Den første samtalen er viktig både for å etablere tillit og fordi en stor utfordring i dette arbeidet er barnas lojalitet overfor foreldrene og dermed hemmeligholdelse av alvorlige vansker i familien. Flere av kapitlene har også rammer med forslag til refleksjonsoppgaver for studenter på ulike nivåer.

Den primære målgruppen er studenter på bachelor- og masternivå innen barnevern og sosialt arbeid, i tillegg til barneansvarlige og behandlere innen rusomsorg og psykisk helsevern. De fleste kliniske eksemplene er hentet fra rus og psykiatri, men fremstillingen er også meget relevant for arbeid innen generell helsetjeneste, bl.a. med eksempel på betydningen av kulturelle forskjeller i sykdomsoppfatning. Fremstillingen bidrar også til å understøtte forståelsen av hvor viktig det er med tilgjengelige helsesøstre i skolen og at barnevernet har tilstrekkelig kompetanse. Barneansvarlig kan være usikker på barnets psykiske tilstand og kan gjennom kartlegging komme frem til at barnet trenger barnepsykiatrisk vurdering. Da kan det også være viktig å vite at det fra 2010 kan være tilstrekkelig at en av foreldrene samtykker ved henvisning dersom «kvalifisert helsepersonell vurderer at helsehjelpen er nødvendig for å unngå skade».

Litteraturlisten inneholder relevant litteratur, både hva gjelder basal kunnskap om temaet og norske artikler og rapporter. I tillegg er det sju forslag egnet for barn og foreldre, men jeg savner en stikkordliste.

Innhold og form gjør at boken etter min mening er godt egnet for helsepersonell som møter barn og unge i ulike risikosituasjoner og som, basert på en helhetstenkning, ønsker å utnytte hjelpeapparatets muligheter til å bidra til god utvikling og trivsel for barn i ulike aldre og familiesituasjoner.

\section{Barn som pårørende}

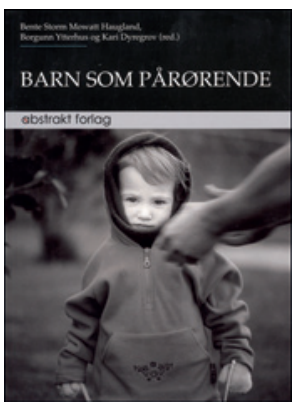

Bente Storm Mowatt Haugland,

Borgunn Ytterhus, Kari Dyregrov, red.

Barn som pårørende

221 s, tab, ill. Oslo: Abstrakt forlag, 2012

Pris NOK 345

ISBN 978-82-7935-324-9

Barn er ikke pårørende slik voksne er det. De er knyttet til sine foreldre på godt og vondt, og når foreldrene pga. egen sykdom eller rusproblemer ikke er i stand til å utøve foreldreskapet til barnas beste, står barna i fare for å utvikle alvorlige psykososiale problemer. 1. januar 2010 fikk helsepersonelloven og spesialisthelseloven bestemmelser om at disse barna, med foreldrenes samtykke, skal få informasjon om foreldrenes tilstand og nødvendig oppfølging fra hjelpeapparatet. Lovbestemmelsene har som hensikt å sikre at risikoutsatte barn og unge får tidlig hjelp og sette barn og foreldre bedre i stand til å mestre situasjonen.

Denne boken er resultat av et samarbeid mellom erfarne klinikere og forskere initiert av BarnsBeste - Nasjonalt kompetansenettverk for barn som pårørende (opprettet av Helse- og omsorgsdepartementet i 2007). Redaktørene er anerkjente forskere i psykologi og sosiologi, og de har gjennom sin forskning bidratt til å synliggjøre disse barna både i politiske og barnefaglige fora. De har med seg sju bidragsytere, og sammen tar de for seg lovgrunnlaget, barnas situasjon når foreldrene har en alvorlig kreftsykdom, nevrologisk sykdom eller skade, psykiatrisk sykdom eller rusproblemer, og den særlige risikoen de yngste barna er i når mor er deprimert. Et av kapitlene handler om den særlige utfordringen for barn som pårørende i minoritetsfamilier. I tillegg tar forfatterne for seg tiltak som pedagogiske samtalegrupper for barn og familiesamtaler med barneperspektiv når mor eller far har en psykisk lidelse, og de formidler erfaringsbaserte råd til de barneansvarlige i spesialisthelsetjenesten.

Boken er oversiktlig disponert, og artiklene har gode kildehenvisinger. Den er lettlest og har et godt og presist språk. Målgruppen er profesjonsutøvere som møter barn som pårørende i spesialisthelsetjenesten, i fastlege- og helsesøstertjenesten, i skole, barnehage og barnevern. Barn som pårørende har alltid eksistert. De siste årene er imidlertid deres behov for støtte blitt anerkjent bl.a. gjennom lovverket, og da er det vesentlig at de blir møtt på en utviklingsfremmende måte av det profesjonelle hjelpeapparatet.

Forfatterne vektlegger betydningen av å arbeide sammen med foreldrene for å støtte barna, og et hovedpoeng blir derfor hvordan hjelperne klarer å gjøre barnas situasjon til relevante temaer i møtene med de syke og rusmisbrukende foreldrene. Jeg anbefaler boken på det sterkeste.

\section{Marit Hafting}

BUP Voss

Voss sjukehus 